УДК 65.011:330.133

Кривов'язюк I.В., к.е.н., професор

Професор кафедри підприємництва, торгівлі та біржової діяльності Kryvovyazyuk I., PhD in Economics, Professor Professor of the Department of Entrepreneurship, Trade and Stock Exchange Activity https://orcid.org/0000-0002-8801-4700 Бурбан О.В. Аспірант кафедри підприємництва, торгівлі та біржової діяльності Burban A. Postgraduate student of the Department of Entrepreneurship, Trade and Stock Exchange Activity https://orcid.org/0000-0002-6130-8397

\title{
КОМПАРАТИВНИЙ АНАЛІЗ НАУКОВО-МЕТОДИЧНИХ ПІДХОДІВ ДО ОЦІНЮВАННЯ ВАРТОСТІ ПІДРИЕМНИЦЬКИХ СТРУКТУР
}

\author{
Луцький національний технічний університет
}

\begin{abstract}
В статті на основі результатів порівняльного аналізу методичних підходів до оцінювання вартості подальшого розвитку набули теоретико-методичні засади встановлення вартості підприємницьких структур, що визначають важливість використання синтезу методів. Шляхом критичного аналізу публікацій вчених у сфері дослідження оцінювання вартості підприємницьких структур уточнено площину дослідження науково-методичних підходів, які застосовуються для іiї встановлення. Уточнено особливості вживання тих чи інших назв витратного, доходного та порівняльного підходів. В результаті аналізу основних підходів до оцінювання вартості підприємницьких структур розкрито їх основні переваги та недоліки. Аналіз методів оцінки вартості підприємницьких структур в розрізі доходного підходу дозволив встановити, що основними методами оцінки вартості тут є дисконтування грошових потоків, капіталізації надлишкового доходу, капіталізації дивідендів та капіталізації чистого доходу. Найбільш універсальним є метод дисконтованих грошових потоків, який незважаючи на велику кількість припущень та складність розрахунків, дозволяє врахувати майбутній їх потенціал, можливий рівень зростання галузі функціонування підприємницьких структур, а також ступінь впливу макроекономічних трендів. Визначено, що в межах витратного підходу найбільшим недоліком значної кількості методів (методи визначення ліквідаційної вартості, чистої балансової вартості, вартості заміщення, відновної вартості, скоригованої балансової вартості та оцінювання чистої ринкової вартості матеріальних активів) виступає складність доступу до необхідної інформації. Найбільш досконалим 3 точки зору об'єктивності та доступності інформації серед таких методів оцінювання вартості, виступає метод відновної вартості, а найбільш універсальним виступає метод ліквідаційної вартості. Встановлено, що в межах порівняльного підходу найбільшого поширення набув метод галузевих коефіцієнтів, а найбільш оптимальним виступає метод компаній-аналогів, який гарантує високий рівень об'єктивності та дозволяє порівняти об'єкт оцінки 3 компаніями-конкурентами забезпечуючи при цьому широкий діапазон вибору мультиплікаторів.

Ключові слова: оцінювання вартості, доходний підхід, витратний підхід, порівняльний підхід, порівняльний аналіз, підприємницькі структури.
\end{abstract}

\section{COMPARATIVE ANALYSIS OF METHODOLOGICAL APPROACHES TO ENTREPRENEURIAL STRUCTURES VALUATION}

\author{
Lutsk National Technical University
}

In the article based on the results of comparative analysis of methodological approaches to valuation of entrepreneurial structures further development impulse was given to theoretico-methodological base of company valuation which highlights importance of using synthesis of methods. Having critically analyzed publications in the field of researching entrepreneurial structures valuation the main area of researching of methodological approaches which are used for valuation was specified. The main nuances of using of titles of income, cost and comparable approaches were specified. The result of analysis of basic entrepreneurial structure valuation approaches was embodied into their pros and cons list. The analysis of the entrepreneurial structure valuation methods allowed to reveal that the list of the main valuation methods within income approach includes discount 
cash flow method, residual income method, dividend capitalization method, net income capitalization method and earning capitalization method. The most universal method within mentioned approach is discount cash flow method, which, despite having a huge number of assumptions and calculation complication, allows to include the future potential of cash flow, approximate growth level in the enterprenurial structure functioning industry and the level of influence from macroeconomic trends. It was defined that the most essential disadvantage of the methods included into cost approach (determining liquidation value mathods, net book value method, replacement cost method, replacement value method, adjusted book value method and estimation of net market value of tangible assets method) is a low level of access to necessary information. The most advanced valuation method in the terms of objectivity and access to information within mentioned approach is replacement value method, the most universal one is liquidation value method. It was discovered that within comparable approach the most common is relative valuation method and the most advanced one is comparable company valuation method which provides a high level of objectivity and allows to compare the company with its competitors ensuring at the same time a wide multiplicator range.

Key words: valuation, income approach, cost approach, comparable approach, comparable analysis, enterprenerial structures.

Постановка проблеми у загальному вигляді та іï зв'язок 3 важливими науковими та практичними завданнями. В сучасних умовах господарювання для підприємницьких структур, що функціонують в ринковому середовищі, надзвичайно важливим аспектом $є$ узагальнене уявлення про всю різноманітність господарських процесів, подій та явищ, а також результатів їхньої діяльності, що формується на основі оцінювання вартості. Якісна та справедлива оцінка вартості підприємницьких структур залежить від багатьох умов і обмежень, серед яких виключну роль відіграють обрані науково-методичні підходи або ще краще - їх синтез. Наукова основа та порівняльний аналіз існуючих підходів взмозі вирішити ряд таких проблем як об'єктивність вибору методу оцінювання вартості підприємницької структури в межах обраного підходу, доцільність застосування методів для отримання справедливої ії вартості, оптимальність застосування методу залежно від цілей оцінювання підприємницьких структур. В сукупності це й викликає об'єктивну потребу чіткого розмежування та систематизації наявних підходів оцінювання вартості підприємницьких структур, що має важливе значення для визначення їх інвестиційної привабливості, рейтингування, визначення вартості під час продажу на ринку.

Аналіз останніх досліджень і публікацій, в яких започатковано вирішення проблеми. Дослідженням науково-методичних підходів оцінювання вартості підприємницьких структур займалось багато вітчизняних i зарубіжних учених. Особливої уваги заслуговують праці В. Задерея [1], А. Сендеровича [2], В. Куцика та I. Явтуховської [3], І. Коваля [4], Г. Міокової [5], В. Мартинюка та О. Вівчар [6], В. Павлова та I. Пилипенка [7], Ю. Сівіцької [8], Д. Жерліцина [9] та інших [10-11]. Зазначені учені провели особливо грунтовний аналіз та розкрили характеристики основних методів оцінювання вартості підприємницьких структур, зокрема такої їх організаційно-правової форми як підприємство, в межах наявних підходів - витратного, дохідного та порівняльного; визначили особливості ідентифікації методів оцінки ринкової вартості бізнесу, уточнили аналітичні та ринкові показники вартості, вказали на важливість комбінування методів при оцінці вартості компаній. Однак, незважаючи на глибину аналізу, найбільша невизначеність, пов'язана із розбіжностями виокремлення методів оцінювання в межах трьох основних підходів, залишається невирішеною. Тому проблема подальшого розвитку теоретико-методичних засад встановлення вартості підприємницьких структур шляхом систематизаціїі та компаративного аналізу науковометодичних підходів до оцінювання вартості підприємницьких структур все ще є важливим і актуальним завданням сьогодення.

Мета статті полягає у систематизації та узагальненні сучасних науковометодичних підходів до оцінювання вартості підприємства шляхом здійснення їх компаративного аналізу. 
Виклад основного матеріалу дослідження 3 повним обгрунтуванням отриманих наукових результатів. Оцінювання, в сучасному трактуванні, являє собою певний аналітичний інструмент чи основу, призначення якої полягає у вимірюванні ефектів, результативності та наслідків реалізації державних чи галузевих програм, програм розвитку, корпоративних програм тощо, визначенні змін за результатами 3 метою підготовки необхідного підгрунття для прийняття рішень [12, с. 23-26]. Це стосується рівно як підприємницьких структур, так й, зокрема, підприємств.

Як відзначають В. Куцик та I. Явтуховська, «оцінювати бізнес можна за різними підходами та методами. Підхід являє собою певну сукупність методів і процедур, які утворилися на основі розвитку певних моделей, течій тощо і за допомогою яких оцінюється вартість підприємства» [3, с. 83]. Адекватність вибору підходу може суттєво вплинути на подальше розгортання подій відносно перспективності розвитку підприємницьких структур.

Сам же процес оцінювання вартості підприємства, в загальному вигляді, можна розподілити на два рівні. На першому рівні відбувається відбір науково-методичних підходів оцінювання, яких на сьогоднішній день 3 традиційної точки зору виділено три - витратний, дохідний та ринковий (порівняльний). Характеризуючи зазначені підходи, такі автори як В. Павлов і І. Пилипенко підкреслюють, що витратний підхід включає оцінку повного відтворювання або встановлення вартості повноцінного заміщення оцінюваного об'єкта після вираховування вартості всіх видів зносу. Дохідний підхід формується на основі принципів найефективнішого використання та очікування, відповідно до яких вартість встановлюється як поточна вартість очікуваних доходів від найбільш ефективного використання об'єкта оцінки, включаючи дохід від його можливого перепродажу. Порівняльний підхід в своїй основі базується на врахуванні принципів заміщення та ринкової кон'юнктури, і також включає аналіз цін продажу та пропозиції з коригуванням вартості на сукупність відмінностей між об'єктами порівняння та об'єктом оцінки [7, с. 702-758]. На другому рівні, в розрізі обраних підходів, здійснюється підбір найбільш оптимального синтезу методів оцінювання вартості.

Аналіз наукових напрацювань учених також дозволяє уточнити особливості вживання тих чи інших назв витратного, доходного та порівняльного підходів з метою уникнення семантичної плутанини. Так, В. Задерей та А. Сендерович, характеризуючи ці підходи надають перевагу тріаді «дохідний-затратний-ринковий» $[1,2]$, В. Мартинюк та О. Вівчар схильні до вживання назв відповідно «прибутковий», «майновий» та «порівняльний» [6]. І. Явтуховська та В. Куцик [3] поряд із трьома традиційними підходами підкреслюють виникнення четвертого - «опціонного» підходу, «який пов'язаний із застосуванням опціонних моделей оцінки вартості підприємства» [3, с. 84]. Протилежної думки стосовно опціонного підходу дотримуються О. Шевчук і А. Зименко, які розглядають метод реальних опціонів (ROV) в межах доходного підходу. Так, зазначені учені вважають, що «ROV-метод відноситься перш за все до доходного підходу, оскільки орієнтований на визначення майбутньої прибутковості та дає можливість мати значну кількість варіантів 3 вартості об'єкту оцінки, тобто $\mathrm{ROV}$-метод уточнює уявлення про майбутню динаміку бізнесу з урахуванням моменту часу» $[10$, с. 132]. Варто підкреслити розбіжності у поглядах учених, які зумовлені назвою підходу, заснованого на оцінці доходів підприємства. Найбільш поширеною назвою зазначеного підходу є «дохідний», також широкого розповсюдження набула практика використання назви «доходний». Менш поширреною $\epsilon$ назва «прибутковий». Іншими часто вживаними назвами для традиційного «витратного» підходу (вартість підприємства відповідно до якого визначається різницею між вартістю його активів та зобов'язань) $\epsilon$ «затратний» та «майновий». Виникнення останньої обумовлено 
ототожненням підприємства (в межах даного підходу) з цілісним майновим комплексом. Менше різноманіття назв спостерігається для третього підходу - заснованого на зіставленні вартості підприємства із компаніями-аналогами. Так, значного поширення набуло використання назв «ринковий» та «порівняльний». Пропонуємо в подальшому вживати такі назви методів як доходний, витратний та порівняльний.

Як показує аналіз змісту наукових публікацій, методологія оцінки вартості суб'єкта господарювання, в загальному вигляді, включає в себе три основних підходи (доходний, витратний та порівняльний), в межах яких виокремлюють перелік основних методів оцінки. Грунтовний аналіз зазначених науково-методичних підходів до оцінювання вартості підприємництких структур, дозволяє узагальнити їх сутність, а також уточнити їх основні переваги та недоліки (таблиця 1).

Таблиця 1

Аналіз основних підходів до оцінки вартості підприємницьких структур

\begin{tabular}{|c|c|c|c|}
\hline Підхід & Сутність & Переваги & ліки \\
\hline Доходний & $\begin{array}{l}\text { Базується на оцінці майбутніх } \\
\text { доходів, коли оцінка вартості } \\
\text { грунтується на визначенні } \\
\text { теперішньої вартості майбутніх } \\
\text { вигод (доходів, грошових } \\
\text { потоків) від } \\
\begin{array}{l}\text { корпоративними } \\
\text { підприємства }\end{array}\end{array}$ & $\begin{array}{l}\text { 1) вартість напряму } \\
\text { залежить від грошового } \\
\text { потоку; } \\
\text { 2) враховує } \\
\text { макроекономічні тренди } \\
\text { та галузеві тенденції; } \\
\text { 3) враховує здатність } \\
\text { активів до генерування } \\
\text { грошових потоків. }\end{array}$ & $\begin{array}{l}\text { 1) заснована на великій } \\
\text { кількості припущень; } \\
\text { 2) складність } \\
\text { розрахунків; } \\
\text { 3) супроводжується } \\
\text { високим ступенем } \\
\text { суб'єктивізму. }\end{array}$ \\
\hline Витратний & $\begin{array}{l}\text { Грунтується на уявленні про } \\
\text { підприємство як цілісний } \\
\text { майновий комплекс, вартість } \\
\text { якого визначається різницею } \\
\text { між вартістю активів та його } \\
\text { зобов'язань }\end{array}$ & $\begin{array}{l}\text { 1) враховує як і } \\
\text { матеріальні, так і } \\
\text { нематеріальні активи; } \\
\text { 2) простота в отриманні } \\
\text { необхідної інформації }\end{array}$ & $\begin{array}{l}\text { 1) невідповідність між } \\
\text { балансовою та ринковою } \\
\text { вартістю майна; } \\
\text { 2)Можливі складнощі } \\
\text { при розрахунку зносу } \\
\text { об'єкта }\end{array}$ \\
\hline Порівняльний & $\begin{array}{l}\text { Заснований на визначенні } \\
\text { вартості як реальної ціни } \\
\text { продажу підприємства-аналога, } \\
\text { розрахунок якої відбувається на } \\
\text { основі результатів його } \\
\text { зіставлення } 3 \text { іншими бізнес- } \\
\text { аналогами }\end{array}$ & $\begin{array}{l}\text { 1) точність завдяки } \\
\text { відсутності припущень; } \\
\text { 2) простота } \\
\text { розрахунків; } \\
\text { 3) порівняння } \\
\text { компаніями-аналогами. }\end{array}$ & 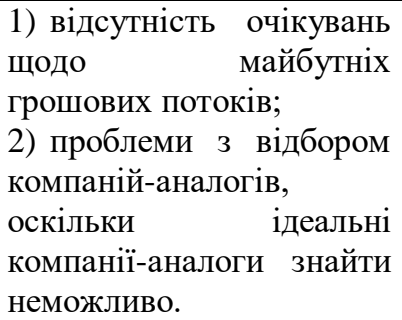 \\
\hline
\end{tabular}

Джерело: авторська розробка на основі [1-11]

В межах кожного з підходів виокремлені методи оцінки вартості, які являють собою конкретні способи, алгоритми обрахунку даної величини. Здійснимо компаративний аналіз основних методів оцінювання вартості підприємницьких структур, результати систематизації яких зведено до таблиці 2.

Проведений аналіз дозволив виявити, що в межах доходного підходу основними методами оцінки вартості підприємства $є$ дисконтування грошових потоків, капіталізації надлишкового доходу, капіталізації дивідендів та капіталізації чистого доходу; в розрізі витратного підходу основними методами оцінки вартості підприємства $\epsilon$ метод ліквідаційної вартості, чистої балансової вартості, метод вартості заміщення, метод відновної вартості, скоригованої балансової вартості та метод оцінювання чистої ринкової вартості матеріальних активів, найбільш універсальним виступає метод ліквідаційної вартості; в рамках порівняльного підходу найбільшого поширення набув метод галузевих коефіцієнтів. 
Таблиця 2

Узагальнення результатів компаративного аналізу основних методів оцінювання вартості підприємницьких структур

\begin{tabular}{|c|c|c|c|c|c|c|c|}
\hline $\begin{array}{c}\text { Назва } \\
\text { підходу }\end{array}$ & Вчені & \multicolumn{6}{|c|}{ Методи } \\
\hline \multirow{6}{*}{ 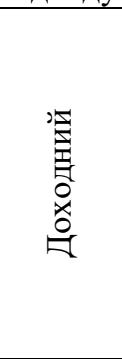 } & В. Задерей & \multirow{6}{*}{\multicolumn{2}{|c|}{$\begin{array}{c}\text { Дисконтування } \\
\text { грошових потоків } \\
(\mathrm{MДГП)}\end{array}$}} & \multirow{2}{*}{$\begin{array}{c}\text { Капіталізація } \\
\text { надлишкового } \\
\text { доходу (МКНД) }\end{array}$} & \multirow{2}{*}{\begin{tabular}{|c|} 
Капіталізації \\
дивідендів \\
(МКД)
\end{tabular}} & \multirow{2}{*}{\multicolumn{2}{|c|}{$\begin{array}{l}\text { Капіталізації чистого } \\
\text { доходу (МКЧД) }\end{array}$}} \\
\hline & А. Сендерович & & & & & & \\
\hline & $\begin{array}{l}\text { В. Куцик, } \\
\text { I. Явтуховська }\end{array}$ & & & \multirow{2}{*}{\multicolumn{4}{|c|}{ Прямої капіталізації доходу (МПКД) }} \\
\hline & І. Коваль & & & & & & \\
\hline & Г. Міокова & & & \multicolumn{4}{|c|}{ Визначення капіталізованої вартості доходів (МВКВД) } \\
\hline & $\begin{array}{l}\text { В. Мартинюк, } \\
\text { О. Вівчар }\end{array}$ & & & \multicolumn{4}{|c|}{ Метод капіталізації (МК) } \\
\hline \multirow{6}{*}{ 懜 } & В. Задерей & \multirow{6}{*}{ 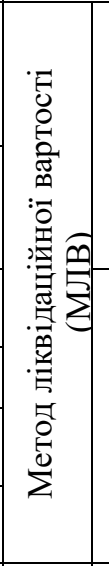 } & \multirow{2}{*}{$\begin{array}{c}\text { Чистої } \\
\text { балансової } \\
\text { вартості } \\
\text { (МЧБВ) }\end{array}$} & \multirow{2}{*}{\begin{tabular}{|c} 
Оцінювання \\
чистої \\
ринкової \\
вартості \\
матеріальних \\
активів \\
(МЧРВМА) \\
\end{tabular}} & \multirow{2}{*}{$\begin{array}{c}\text { Метод } \\
\text { вартості } \\
\text { заміщення } \\
\text { (MB3) }\end{array}$} & \multirow{2}{*}{$\begin{array}{c}\text { Метод } \\
\text { відновної } \\
\text { вартості } \\
\text { (МВB) }\end{array}$} & \multirow{2}{*}{$\begin{array}{c}\text { Скоригованої } \\
\text { балансової } \\
\text { вартості } \\
\text { (МСБВ) }\end{array}$} \\
\hline & А. Сендерович & & & & & & \\
\hline & $\begin{array}{l}\text { В. Куцик, } \\
\text { I. Явтуховська } \\
\end{array}$ & & \multirow{4}{*}{\multicolumn{2}{|c|}{$\begin{array}{l}\text { Метод чистих активів } \\
\text { (МЧА) }\end{array}$}} & - & - & - \\
\hline & І. Коваль & & & & \multicolumn{3}{|c|}{ Метод заміщення (М3) } \\
\hline & Г. Міокова & & & & \multicolumn{3}{|c|}{$\begin{array}{c}\text { Оцінка за відновною вартістю активів } \\
\text { (МОВВА) }\end{array}$} \\
\hline & $\begin{array}{l}\text { В. Мартинюк, } \\
\text { О. Вівчар }\end{array}$ & & & & - & - & - \\
\hline \multirow{5}{*}{ 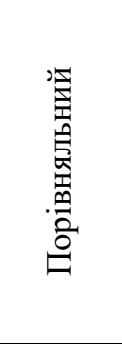 } & В. Задерей & \multirow{5}{*}{ 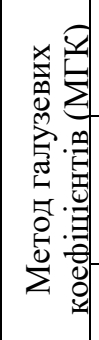 } & \multirow{2}{*}{\multicolumn{2}{|c|}{$\begin{array}{l}\text { Метод порівняння } \\
\text { продажів (МПП) }\end{array}$}} & \multirow{2}{*}{\multicolumn{3}{|c|}{ Метод мультиплікаторів (ММ) }} \\
\hline & А. Сендерович & & & & & & \\
\hline & І. Коваль & & \multirow{2}{*}{\multicolumn{2}{|c|}{$\begin{array}{l}\text { Метод компаній- } \\
\text { аналогів (МКА) }\end{array}$}} & \multirow{2}{*}{\multicolumn{3}{|c|}{ Метод ринкових угод (МРУ) }} \\
\hline & $\begin{array}{l}\text { В. Куцик, } \\
\text { I. Явтуховська }\end{array}$ & & & & & & \\
\hline & $\begin{array}{l}\text { В. Мартинюк, } \\
\text { О. Вівчар }\end{array}$ & & \multicolumn{5}{|c|}{ Метод операцій (угод, продаж) (МО) } \\
\hline
\end{tabular}

Джерело: авторська розробка на основі [1-8]

Встановлено, що дохідний підхід, базуючись на розрахунку майбутніх вигод, приведених до їх теперішньої вартості, відповідає стратегічному підходу трактування вартості. Витратний підхід, маючи в основі уявлення про підприємство, як цілісний майновий комплекс, вартість якого сформована під впливом активів підприємства та його зобов'язань, відповідає витратному підходу трактування даного поняття. Порівняльний підхід до оцінкювання вартості підприємницьких структур, визначаючи діяльність та ступінь розвитку конкурентів (таким чином відображаючи ефективність аналізованого підприємства 3 точки зору співставлення 3 компаніями-аналогами), відповідає синтезу ціннісно-цінового та системного підходів.

Висновки. Сучасні науково-методичні підходи до оцінювання вартості підприємницьких структур, й зокрема підприємств, являють собою складну багатогранну систему із множинною площиною векторів їх подальшого розвитку. Незважаючи на це, в межах методологічного інструментарію основних підходів до оцінювання їх вартості існує докорінна необхідність подальшого розвитку теоретикометодичних засад встановлення вартості підприємницьких структур.

Аналіз методів оцінювання вартості в розрізі доходного підходу дозволив встановити, що найбільш універсальним $є$ метод дисконтованих грошових потоків, який 
незважаючи на велику кількість припущень та складність розрахунків, дозволяє врахувати майбутній потенціал компанії, потенційний рівень росту галузі, а також ступінь впливу макроекономічних трендів. Варто зазначити, що в межах витратного підходу найбільшим недоліком значної кількості методів виступає складність доступу до необхідної інформації. Найбільш досконалим з точки зору об'єктивності та доступності інформації виступає метод відновної вартості. В рамках порівняльного підходу оптимальним виступає застосування методу компаній-аналогів.

Проаналізувавши основні переваги та недоліки групи порівняльних методів оцінки, можемо зробити висновок, що найбільш оптимальним виступає метод компанійаналогів, який забезпечує необхідний рівень об'єктивності встановлення вартості та дозволяє порівняти об'єкт оцінки 3 компаніями-конкурентами, формуючи широкий діапазон вибору мультиплікаторів.

Подальші розвідки у сфері дослідження питань оцінювання вартості підприємницьких структур має бути спрямовано в напрямку удосконалення процесу оцінювання їх вартості, що розкриває оптимальність поєднання дохідного та порівняльного підходів для отримання справедливої його вартості й передбачає дослідження впливу ії зміни на ринкову капіталізацію та одночасне виявлення факторів, що їх спричинили.

\section{Список бібліографічного опису}

1.Задерей В.Ю. Методи оцінки вартості компаній. Агросвіт. 2017. № 5. С. 48-54.

2.Сендерович А.Й. Сучасні моделі оцінки вартості компаній. Інвестиції: практика та досвід. 2015. № 1. C. 99-106.

3.Куцик В.І., Явтуховська І.В. Методи та підходи до оцінки вартості підприємства: теоретичний аспект, проблеми їх використання. Вісник Львівської комериійної академї̈. Серія економічна. 2015. № 48. С. 82-87.

4.Коваль І.Ф. Право на ділову репутацію суб’єктів господарювання і його позасудовий захист від неправомірного використання: Автореф. дис. ... канд. юрид. наук 12.00.04; Інститут економіко-правових досліджень НАН України. Донецьк, 2005.

5.Міокова Г.І. Вартість підприємства та іiі оцінка. Наукові прачі Кіровоградського національного технічного університету. Економічні науки: зб. наук. пр. Кіровоград. 2012. №22 С. 149-156.

6.Вівчар О.І., Мартинюк В.П. Особливості ідентифікації методів оцінки ринкової вартості бізнесу при діагностиці його економічної безпеки. Наука молода: зб. наук. праць молод. вчених Терноп. нац. екон. ун-ту. 2012. № 18. С. $118-122$.

7.Павлов В.І., Пилипенко I.I., Кривов’язюк І.В. Нерухомість в Україні : підручник для студентів вищих навчальних закладів. Київ : Державна академія статистики обліку та аудиту, 2008. 765 с.

8.Сівіцька Ю. Основні питання оцінки вартості сільськогосподарського підприємства. Agricultural and Resource Economics: International Scientific EJournal. 2019. Vol. 5. No. 1. Pp. 137-153. URL: http://are-journal.com.

9.Жерліцин Д.М. Аналітичні та ринкові показники вартості підприємства. Східна європа: економіка, бізнес та управління. 2019. №5. С. 67-72.

10. Kryvovyazyuk I., Smerichevskyi S., Myshko O., Oleksandrenko I., Dorosh V. and Visyna T. Application of Combined Modeling Methods for Estimating and Forecasting the Business Value of International Corporations. International Journal of Management. 2020. № 11(7), pp.1000-1007.

11. Кривов'язюк І.В., Пушкарчук І.М., Волинчук Ю.В. Капіталізації як основа динамічного розвитку підприємств. Економічний форум. 2017. № 1. С. 135-144.

12. Горошко А., Нарчинська Т., Озимок І., Тарнай В. Глосарій термінів 3 моніторингу та оцінювання. 2-е видання. Київ : Українська асоціація оцінювання, 2016. 53 с.

\section{References}

1. Zaderey, V. (2017). Metody otsinky vartosti kompanij [Valuation methods of companies]. Ahrosvit - Agrosvit., 5. 4854.

2. Senderovych, A. (2015). Suchasni modeli otsinky vartosti kompanij [Modern Valuation Models]. Investytsiyi: praktyka ta dosvid-Investments: practice and experience, 1. 99-106.

3. Kutsyk, V. I., Yavtuhovska, I. V. (2015). Metody ta pidkhody do otsinky vartosti pidpryiemstva: teoretychnyj aspekt, problemy ikh vykorystannia [Methods and approaches to the company valuation: theoretical aspect, problems of their use]. Visnyk L'vivs'koi komertsijnoi akademii. Seriia ekonomichna. - Bulletin of the Lviv Commercial Academy. The series is economic, 48. 82-87.

4. Koval, I. F. (2005). Pravo na dilovu reputatsiiu sub'iektiv hospodariuvannia i joho pozasudovyj zakhyst vid nepravomirnoho vykorystannia [The Right to Business Reputation of Enterprises and its Extrajudicial Protection Against Unlawful Use]. Extended abstract of candidate's of tesis. Institute of Economic and Legal Research, National Academy of Sciences, Donetsk [in Ukrainian].

5. Miokova, G. (2012). Vartist' pidpryiemstva ta ii otsinka [The cost of the enterprise and its evaluation]. Naukovi pratsi Kirovohrads'koho natsional'noho tekhnichnoho universytetu. Ekonomichni nauky - Scientific works of Kirovograd National Technical University. Economic sciences, 22. 149-156. 
6. Martinyuk, V., Vivchar, O. (2012). Osoblyvosti identyfikatsii metodiv otsinky rynkovoi vartosti biznesu pry diahnostytsi joho ekonomichnoi bezpeky [Features of authentication methods the estimation market value of business at diagnostics him economic security]. Nauka moloda - Science is young, 18. 118-122.

7. Pavlov, V. I., Pilipenko, I. I., Kryvovyazyuk, I. V. (2008). Nerukhomist'v Ukraini [Real estate in Ukraine]. State Academy of Accounting and Auditing Statistics, Kiev [in Ukrainian].

8. Sivitska, Y. (2019). Osnovni pytannia otsinky vartosti sil's'kohospodars'koho pidpryiemstva [Key issues of agricultural enterprise valuation]. Sil's'kohospodars'ka ta resursna ekonomika - Agricultural and Resource Economics: International Scientific EJournal, 5 (1 ). 137-153. URL: http://are-journal.com.

9. Zherlitsyn, D. (2019). Analitychni ta rynkovi pokaznyky vartosti pidpryiemstva [Analytical and market indicators of enterprise value]. Skhidna ievropa: ekonomika, biznes ta upravlinnia - Eastern Europe: economy, business and management, 5. 67-72.

10. Kryvovyazyuk, I., Smerichevskyi, S., Myshko, O., Oleksandrenko, I., Dorosh, V. and Visyna, T. (2020). Application of Combined Modeling Methods for Estimating and Forecasting the Business Value of International Corporations. International Journal of Management, 11(7). 1000-1007. [in English].

11. Kryvovyazyuk, I. V., Pushkarchuk, I. M., Volynchuk, Y. V. (2017). Kapitalizatsii iak osnova dynamichnoho rozvytku pidpryiemstv [Capitalization as the basic for dynamic development enterprises]. Ekonomichnyj forum - Economic forum, 1. $135-144$.

12. Goroshko A., Narchynska T., Ozymok I., Tarnay V. (2016). Hlosarij terminiv z monitorynhu ta otsiniuvannia [Glossary of terms on monitoring and evaluation]. 2nd edition. Ukrainian Evaluation Association, Kyiv [in Ukrainian].

Дата подання публікації 12.09.2020 р.

УДК 331.341

Лісовська Л.С. , к.е.н, доцент

L. Lisovska, Candidate of Economic Sciences, Associate Professor https://orcid.org/0000-0002-9937-3784

\title{
РОЗВИТОК СПІВПРАЦІ 3 ПИТАНЬ ІННОВАЦІЙ 3 ІНОЗЕМНИМИ ПАРТНЕРАМИ У РЕГІОНАХ УКРАЇНИ
}

\author{
Національний університет «Львівська політехніка»
}

У статті вивчено наведено результати дослідження диференціації інноваційної активності промислових підприємств на основі вивчення показників розвитку співпраці з питань інновацій. Для проведення дослідження було використано кластерний аналіз, зокрема інструменти ізоморфного розподілу та методу куль. Об'єктами спостереження є регіони України та діяльність промислових підприємств, які впроваджували технологічні інновації. Для проведення кластерного аналізу було обрано показники з інноваційної співпраці за місцем розташування партнерів (країни Європи, США, Китай та Індія, інші країни) протягом 2008/2020 pp.

Здійснено систематизацію регіонів України за показниками співпраці підприємств з іноземними партнерами протягом вказаного періоду та доведено асиметричність та диспропорційність розвитку систем взаємодії у регіональному вимірі.

Результати кластерування повинні стати інформаційним забезпеченням моніторингу показників ефективності інноваційних процесів у національній інноваційній екосистемі, їх дослідження на предмет виявлення закономірностей зміни їх ознак у різних економіко-соціальних умовах, а обгрунтовані висновки та пропозиції повинні бути покладені в основу формування регіональної інноваційної політики та інноваційної політики суб'єктів господарювання.

Ключові слова: співпрачя з питань інновачій, технологічні інновачії, кластерний аналіз, іноземний партнер.

\section{DEVELOPMENT OF INNOVATION COOPERATION WITH FOREIGN PARTNERS IN THE REGIONS OF UKRAINE}

\section{Lviv Polytechnic National University}

The main source of the country's economic growth in modern conditions is scientific knowledge and the processes of their expanded production and commercial use. Today, the innovative development of the country in general and the activation of innovation activities in particular depend on the relationships and interaction between the subjects of the economic mechanism for the production of competitive high-tech innovative products (state - 